\title{
REPORT OF THE TREASURER
}

The Treasurer this year again presents to the membership an abridged statement of the Society's financial position, set up in semiinformal narrative style. A copy of the complete Treasurer's Report as submitted to the Trustees and the Council will be sent to any member requesting it from the Treasurer at the Providence office. Moreover, the Treasurer will be happy to answer any questions members may wish to put to him concerning the Society's financial affairs.

The substantial increase in the General Funds of the Society $(\$ 103,280.91)$ is largely a reflection of certain changes in the accounting system-specifically, with respect to the valuation of equipment and the apportionment of overhead. On the same basis as last year the General Funds would have increased $\$ 23,093.58$.

Returns on invested funds this year have been at the rate of $4.47 \%$ computed on book value after deduction of custodial expense. This is very slightly less than last year.

\section{I}

A Description of the Financial Position of the Society AS OF MAY 31, 1960

The Society had Cash on deposit

In the Rhode Island Hospital Trust Company. .... .

In interest-bearing savings accounts.............

In petty cash and drawing accounts in Providence and Los Angeles................... $1,955.00$

It had reserves invested until needed in Government bonds.......

There was owing to it

By the United States Government............

By members, subscribers and others (less allowance

for doubtful accounts) $\ldots \ldots \ldots \ldots \ldots \ldots \ldots \ldots \quad 37,588.97$

It had in stamps and in the postage meter.............. $1,161.64$

It had funds temporarily advanced to certain special accounts..... $\quad 4,713.04$

And it had invested in its Headquarters Building and Office Equipment $115,738.62$

Making a total of Current and Fixed Assets of ............. \$464,783.19

The Society also held investment securities valued at ......... $380,413.01$

(The market value, May 31,1960 was $\$ 440,281.19$ )

Total AssEts, therefore, were...................... $\$ 845,196.20$ 
Offsetting these assets, the Society

Owed members, subscribers and vendors

$\$ 6,840.19$

Held funds received from various special sources to support particular projects, such as the Summer Institute, Summer Seminar, etc................

Had advanced for recovery from future sales for various Society publications-Colloquium and Survey volumes, Birkhoff papers, Translation series, etc.......

Owed to the invested fund account..............

And held in its General Fund the sum of ..........

$12,963.27$

$21,270.19$

$255,923.07$

Thus accounting for all the CURRENT Funds.

The Invested Funds represent the following:

(1) The Endowment Fund, largely the gift of members about thirty-five years ago.............

(2) The Library Proceeds Fund, derived from the sale of the Society's Library in $1950 \ldots \ldots \ldots$. . .

(3) The Prize Funds-Bôcher, Cole, Moore.......

(4) The Mathematical Reviews Fund, a gift received in 1940 to make possible the establishment of the Reviews.........................

(5) Reserves established by the Trustees to protect the life memberships formerly available, and as a "hedge" against investment losses..........

(6) Other funds, derived mainly from bequests to the Society by members, which the Trustees were either required to invest or which they have invested at their option-the income being used for the general purposes of the Society........

A total of INVESTED Funds of

Total Liabilities and Fund Reserves, therefore, were. 
II

\section{An Account of the Financial Transactions of the Society} DURING THE FisCal Year 1959-1960

The Society has two types of receipts-funds for special purposes and projects, and the General Fund, from which are met the general operating expenses of the organization, including the publication of the Bulletin, the Proceedings, the Notices, and the Transactions. Income from sales of and subscriptions to these journals is placed in the General Fund, but in practice is allocated to the expenses of the journals themselves. It is so treated in the following presentation:

To meet its GENERAL obligations, the Society RECEIVED:

From dues and contributions of individual members.

From dues of institutional members...........

From dues of corporate members.............

From sales and support of scientific journals of the

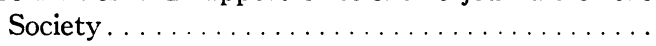

From recovery of indirect costs . . . . . . . . . .

From investment and trusts................

From publication charges. . . . . $2, \ldots \ldots \ldots \ldots \ldots$

From meeting fees...................... $\quad 3,050.50$

From miscellaneous sources............... 2,609.62

Total General Receipts. . . . . . . . . . . . . . . . . . . . . . .

These funds were EXPENDED

For general administrative and meeting expenses... $48,628.89$

For expenses of scientific journals of the Society... $336,987.18$

In subsidies to non-Society publications........ 12,095.60

For miscellaneous expenses............... $\quad 3,409.92$

Total General Expenses. . . . . . . . . . . . . . . . . . . . . . $401,121.59$

Leaving an ExcEsS of INCOME OVER EXPENSES of ........... \$68,617.65

(Which was added to the General Fund)

Scientific Journals of the Society

December 31, 1960

$\$ 469,739.24$

Income Expenses Deficit

Bulletin.

\begin{tabular}{|c|c|c|}
\hline Income & Expenses & Deficit \\
\hline$\$ 12,231.32$ & $\$ 24,074.95$ & $\$ 11,843.63$ \\
\hline $9,350.87$ & $36,602.83$ & $27,251.96$ \\
\hline $12,082.50$ & $31,536.64$ & $19,454.14$ \\
\hline $51,794.83$ & $64,032.87$ & $12,238.04$ \\
\hline $161,874.95$ & $180,739.89$ & $18,864.94$ \\
\hline$\$ 247,334.47$ & $\$ 336,987.18$ & $\$ 89,652.71$ \\
\hline & \multicolumn{2}{|c|}{$\begin{array}{l}\text { Respectfully submitted, } \\
\text { AlBERT E. MEDER, JR. } \\
\text { TREASURER }\end{array}$} \\
\hline
\end{tabular}

Proceedings

Notices . . . . . . . . . . . . . . . . . . .

Transactions....................

Mathematical Reviews

Totals

$\ldots \ldots \ldots \ldots \ldots \ldots \ldots \ldots$ 